Expl Agric. (2002), volume 38, pp. 291-315 C 2002 Cambridge University Press

DOI:10.1017/S0014479702003046 Printed in the United Kingdom

\title{
ANALYSIS OF ENSET (ENSETE VENTRICOSUM) INDIGENOUS PRODUGTION METHODS AND FARM- BASED BIODIVERSITY IN MAJOR ENSET-GROWING REGIONS OF SOUTHERN ETHIOPIA
}

\author{
By A. TSEGAYE $\uparrow+$ and P. C. STRUIK $\$$ \\ $\dagger$ Debub University, Awassa College of Agriculture, P.O. Box 5, Awassa, Ethiopia and \\ +Wageningen University, Department of Plant Sciences, Crop and Weed Ecology group, \\ Haarweg 333, 6709 R2 Wageningen, The Netherlands
}

(Accepted 5 January 2002)

\section{SUMMARY}

\begin{abstract}
Enset (Ensete ventricosum) production is declining, and it faces genetic erosion due to drought, diseases and population pressure. Participatory Rural Appraisal (PRA) and additional formal survey studies on 315 households were conducted over three consecutive years (1998-2000) in the Sidama, Wolaita and Hadiya ethnic regions of southern Ethiopia to assess traditional cultivation methods, analyse the production systems, and evaluate farm-based enset biodiversity. The regions differ in terms of cultural background, resources, farming systems, population density, and agro-ecology. Furthermore, the methods for initiating suckers and the frequency of transplanting vary among the three regions.

Diverse enset landraces were identified in the Sidama (52), Wolaita (55) and Hadiya (59) regions. Sidama farmers had the highest number of landraces per farm, $57 \%$ and $21 \%$ more than found on Wolaita and Hadiya farms respectively. In all three regions, landrace diversity was influenced by household resources, cultural background, population pressure, and agro-ecology. There were significant differences in the average number of enset landraces and livestock between rich and poor households in the three regions. Rich farmers had more land and manure-producing livestock, and they planted more enset landraces than did poor farmers. In all three regions, women proved to be more experienced than men in identifying enset landraces.

The number of enset landraces per farm was significantly correlated with other household characteristics for resource-rich Sidama farmers and with the number of livestock and area of farmland for resource-rich Hadiya farmers. This suggests that middle-income or poor farmers concentrate on annual crops, rather than on growing the perennial enset plant. More research is needed to identify, characterize and conserve genetic diversity, and to improve the cultivation practices for enset. The cultural, socio-economic, and gender-associated aspects of enset cultivation need to be assessed to understand the dynamics of enset biodiversity.
\end{abstract}

\section{INTRODUCTION}

There are four major farming systems in Ethiopia: pastoralism, shifting cultivation, the seed-farming complex, and the enset (Ensete ventricosum)-planting complex

Corresponding author: Admasu Tsegaye, Wageningen University, Department of Plant Sciences, Crop and Weed Ecology group, Haarweg 333, 6709 RZ Wageningen, The Netherlands. Tel.: +31 (0) 317 485312; Fax: +31 (0) 317 485572; E-mail: Admasu.Tsegaye@CWE.DPW.WAU.NL 
(Westphal, 1975). Of these, the enset-planting complex is the most sustainable indigenous farming system that can support the densely populated highlands of the south and south-western parts of Ethiopia.

Enset is one of the oldest cultivated plants in Ethiopia. Anthropologists, archaeologists, historians, and other scholars argue that domestication of enset in Ethiopia occurred as early as 10000 years ago (Brandt et al., 1997). The highlands of southern Ethiopia form the geographical centre of enset cultivation (Vavilov and Rodin, 1997), and the various ethnic groups in this region recognize and exploit many enset landraces.

Within the enset production systems, seven to ten million people cultivate the crop as a staple food, or as a co-staple with cereals and root- and tuber crops. Enset produces a starchy food from its vigorous pseudostem, its corm, and from the stalk of its inflorescence. A mixture of scraped pseudostem pulp, the pulverized corm, and the stalk of the inflorescence is fermented in a pit. The resultant product is called 'kocho' locally. Although many different dishes are prepared from kocho, most common are a pancake-like bread and porridge. Furthermore, the corm can be cooked fresh and consumed in a way similar to Irish potato, sweet potato, or cassava. Enset also provides good quality fibre and, with the exception of the roots, all plant parts can be used for livestock feed. Local people also believe that particular enset landraces have various medicinal properties.

Livestock play an important role in maintaining soil fertility, in providing milk and meat, and as a source of cash in times of need. Farmers grow their enset crops closest to their houses for easier fertilization with cow dung and household refuse. Cereals, root- and tuber crops are generally grown in areas further from the house. Young enset plants are intercropped with annuals (such as maize, common bean, cabbage, taro, and Irish potato), and older enset plants with perennials (such as avocado, coffee, and citrus) (Tsegaye and Struik, 2000).

According to the farmers 'enset is the enemy of hunger, and human and livestock life is impossible without it'. Despite its importance for food security and environmental sustainability, however, little research and development work has been done on enset production systems. The Ethiopian government has focused its agricultural research and development efforts mainly on high-yielding annual crops that can be marketed. The attention of the government towards encouraging the adoption of these new technologies has resulted in a shift from enset- to cereal-based agriculture. As a result, some enset growing regions have experienced famine in recent years, something unknown to past generations.

Recently, awareness of the importance of enset for food security and environmental sustainability has increased. For instance, some communities that had shifted from enset to cereal production have started to grow enset again as their recent experience with famine has caused them to appreciate enset's capacity to prevent hunger. In addition, enset production systems are being promoted outside of the traditional enset region, not only in adjacent areas but also in areas far to the north and east of Ethiopia where, historically, the population has depended mainly on cereal crops. 
Little is known about enset-based farming systems, however, particularly with respect to production systems, cultivation methods and genetic diversity. Average farm sizes have decreased with increasing population, and traditional technologies and practices have failed to produce enough enset to feed the population. The crop has a long growing cycle and gives low yields in traditional production systems. Because enset cultivation spans several different ethnic groups and agroecological zones, production methods and processing procedures vary greatly. In order to improve traditional enset production systems, indigenous knowledge from the different enset growing regions needs to be analysed and understood. Such an improved understanding of indigenous knowledge related to enset production can help to identify guidelines for selecting potentially interesting topics for scientific research (Bellón, 1991; DeWalt, 1994).

Diseases, insect pests and drought have also threatened the production of enset. Though some characterization of the crop's genetic diversity has been done, identification of plant material with resistance to diseases and pests, or with the capacity to excel in specific environments, has not begun yet.

The few available sociological or survey studies on enset farming systems cover sample areas too small to be representative of the entire region (e.g. Spring et al., 1996). Furthermore, the little research and development effort that has been addressed to enset has not been based on farmers' needs, and has thus failed to address their production constraints. This research, therefore, aimed to: (i) describe and evaluate current indigenous knowledge on production methods and production constraints; (ii) identify the existing diversity and its potential use in improving the production systems; and (iii) identify household characteristics that determine enset's production and biodiversity.

MATERIALS AND METHODS

Study areas

Participatory Rural Appraisal (PRA) and formal survey studies were conducted over three consecutive years (1998-2000) in three densely-populated ensetgrowing regions, inhabited by the Sidama, Wolaita, and Hadiya ethnic groups (Figure 1).

Hagereselam (2600 - $2650 \mathrm{~m}$ asl), with a population density of 299 persons $\mathrm{km}^{-2}$, was selected as the study site in the Sidama region. The local people, who speak a Cushitic language, depend heavily on enset for food. The Wolaita belong to the Omotic linguistic family. They cultivate enset as a co-staple, along with cereals, roots and tubers. The study site in their area was Areka (1750-1820 m asl), which has a population density of 348 persons $\mathrm{km}^{-2}$. The Hadiya people speak a Cushitic language and also cultivate enset as a co-staple with cereal or pulse crops. In the Hadiya ethnic region, the authors selected Anna-lemmo (2220-2400 m asl) and Ambicho Gode (1900-2000 m asl) for the study, both with population densities of 278 persons $\mathrm{km}^{-2}$.

Hagereselam, Areka, and Anna-lemmo/Ambicho Gode are, respectively, 150, 


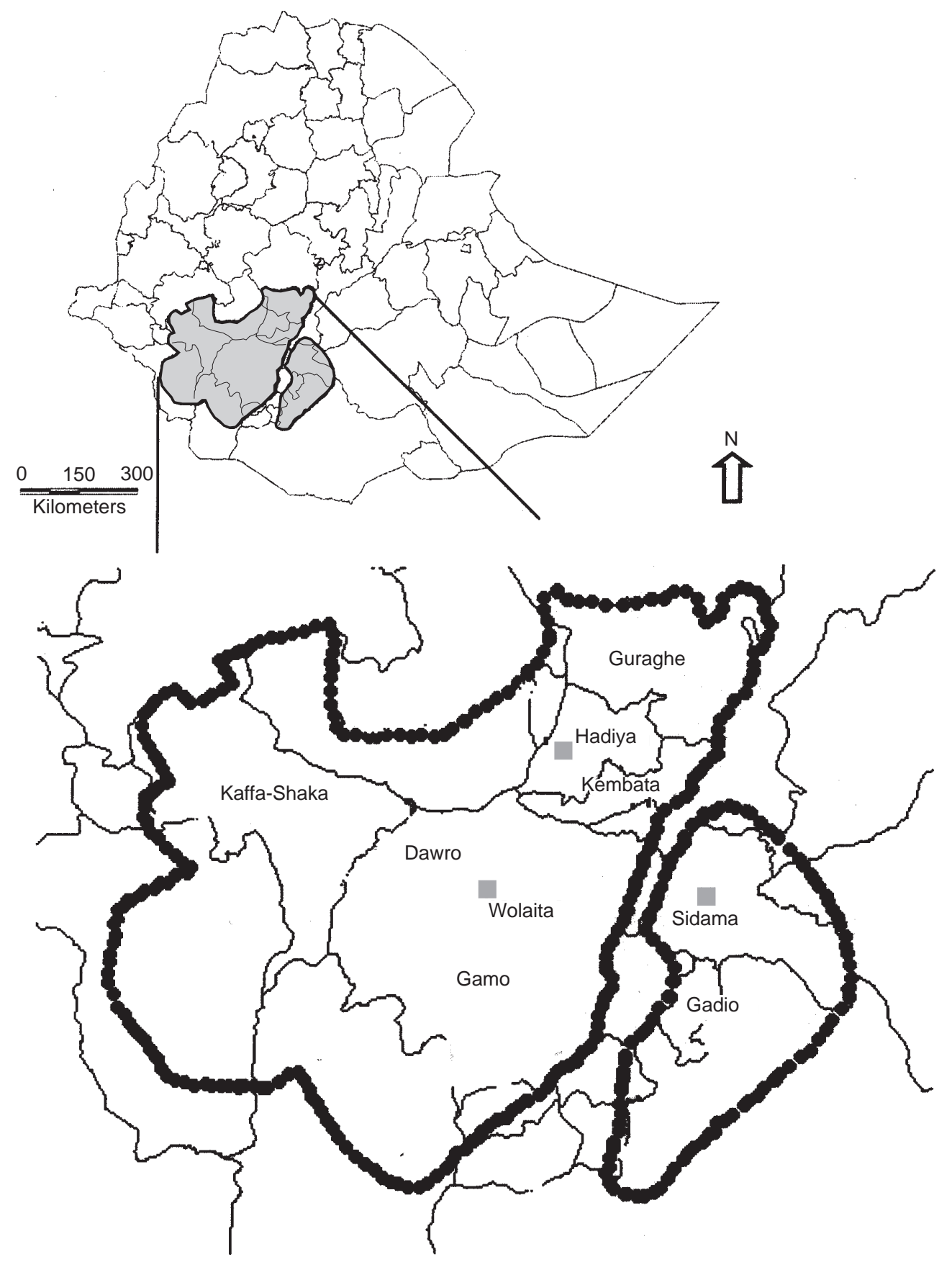

Figure 1. The major enset-growing regions and the study areas in Ethiopia. 
205 and $350 \mathrm{~km}$ from Awassa, the main town of the Southern Nations Nationalities and People's Regional State. Besides ethnicity, the three regions differ in cultural background, resources, farming systems, population density and agro-ecology.

\section{Wealth ranking}

In each study area, 105 households were chosen randomly. Community leaders and eight key informants participated in a wealth-ranking exercise in which they were asked to identify indicators of household wealth or well-being, and to group neighbouring households according to their relative wealth. The key informants sorted a number of cards, each with one household name recorded on it, into three separate piles one each for rich, middle and poor households. This ranking system was used to establish the overall wealth distribution, and to calculate the proportion of each category in each village. The researchers visited all 315 farming households in the three study areas and conducted group and individual discussions, gathering data using semi-structured interviews and PRA methods.

\section{Cultivation methods}

During the household surveys, the researchers were able to directly, and repeatedly, observe cultivation activities such as propagation, transplanting, leaf pruning, weeding, fertilization and the planting pattern, thereby obtaining detailed and consistent descriptions. Some activities could not be observed and, therefore, were described by the farmers themselves. For each area, the compiled information on cultivation methods was presented to a group of representative farmers for feedback and discussions to gain agreement on the common local methods of cultivation.

\section{Household characteristics}

Group discussions with farmers identified crop species, livestock, farm size and family size as the most important household characteristics in their production system. In all three enset-growing study areas, a group of male and female key informants were asked to name all the enset landraces and crop species grown there. This information was used to develop and pre-test a formal questionnaire survey which was conducted at household level. For each household, the survey recorded the number of enset landraces, the vernacular name of each landrace, other crop species, the number of livestock, the monthly share of main crops consumed, family size and farm size.

\section{Data categorization and analysis}

In order to assess the diversity of enset within each wealth category, the names of all enset landraces grown in each region were listed, tallying landrace presence by household, to determine the percentage occurrence of a landrace in each wealth category. The collected data were then analysed with descriptive statistics, treating each household as a replication and using a logarithmic transformation of 
Table 1 . Wealth ranking by community leaders and key informants at Hagereselam, Sidama region.

\begin{tabular}{|c|c|c|}
\hline $\begin{array}{l}\text { Wealth } \\
\text { category }\end{array}$ & Wealth indicators & $\%$ \\
\hline $\begin{array}{l}\text { Rich } \\
\dagger \text { (Duresa) }\end{array}$ & $\begin{array}{l}\text { - } 2-3 \text { farm lands, each with wives and children } \\
\text { - Large, beautiful, traditional houses in all farm lands } \\
\text { - More than } 40 \text { dairy cattle } \\
\text { - More than } 10 \text { oxen and many sheep and goats } \\
\text { - More than } 10 \text { horses for transportation and hauling } \\
\text { - Do not buy agricultural products from market } \\
\text { - Own natural forest and do not sell the products, but give freely to people } \\
\text { - More than } 1 \text { ha of enset plantation, with many flowering enset plants at } \\
\text { - } \text { - More than land } 1 \text { ha of bamboo plantation at each farm land } \\
\text { - Store large quantities of wheat and barley for sale } \\
\text { - Provide children all necessary traditional requirements for marriage }\end{array}$ & 12 \\
\hline $\begin{array}{l}\text { Middle } \\
\dagger(\text { Mererima })\end{array}$ & $\begin{array}{l}\text { - } 2 \text { farm lands, each with wives and children } \\
\text { - Beautiful traditional houses in both farm lands } \\
\text { - About } 30 \text { livestock, including dairy cattle, oxen, sheep and goats } \\
\text { - } 1-4 \text { horses for transportation and hauling } \\
\text { - } 0.5 \text { ha enset plantation, with some flowering plants in both farm lands } \\
\text { - } 0.5 \text { ha bamboo plantation in both farm lands } \\
\text { - Own natural forest } \\
\text { - Do not buy agricultural products from market } \\
\text { - Store wheat and barley for sale }\end{array}$ & 62 \\
\hline $\begin{array}{l}\text { Poor } \\
\dagger \text { (Buticho) }\end{array}$ & $\begin{array}{l}\text { - One farm land and one wife } \\
\text { - Small traditional house, not properly roofed with bamboo } \\
\text { - } 1-3 \text { livestock } \\
\text { - Sell agricultural products immediately after harvest } \\
\text { - Small area of enset plantation } \\
\text { - Do not have flowering enset plants } \\
\text { - Consume enset plants before maturity } \\
\text { - Sell labour to rich } \\
\text { - Do not pay tax on time }\end{array}$ & 26 \\
\hline
\end{tabular}

$\dagger$ Local names for rich, middle, and poor households

household characteristics to account for non-normal distributions. The coefficient of determination $\left(\mathrm{r}^{2}\right)$ was computed to determine the linear relationships among the household characteristics.

RESULTS

\section{Wealth classification}

Tables 1 to 3 present the wealth indicators, as defined by community leaders and key informants in the three ethnic regions. In Sidama and Hadiya, a large proportion of the population fell in the middle wealth category, whereas in Wolaita the proportion of resource-poor households was the highest. The combined proportion of rich and middle-income households was $74 \%, 60 \%$ and 
Table 2. Wealth ranking by community leaders and key informants in Areka, Wolaita region.

\begin{tabular}{|c|c|c|}
\hline $\begin{array}{l}\text { Wealth } \\
\text { category }\end{array}$ & Wealth indicators & $\%$ \\
\hline $\begin{array}{l}\text { Rich } \\
\dagger \text { (Durre) }\end{array}$ & $\begin{array}{l}\text { - Land area more than } 1 \text { ha } \\
\text { - Own house with a corrugated iron sheet roof } \\
\text { - } 5-7 \text { dairy cattle } \\
\text { - } 2-3 \text { oxen } \\
\text { - } 1-2 \text { mules for transportation } \\
\text { - } 4 \text { donkeys } \\
\text { - Store agricultural products for sale } \\
\text { - Do not buy agricultural products from market } \\
\text { - Many coffee plants } \\
\text { - More than } 10 \text { flowering enset plants } \\
\text { - Send all children to school } \\
\text { - Loan livestock out to poorer neighbours, who feed and shelter them } \\
\text { - Many eucalyptus trees } \\
\text { - Sell } 3-15 \text { fattened animals for traditional holidays } \\
\text { - Lend money on credit } \\
\text { - Hire daily labourers }\end{array}$ & 12 \\
\hline $\begin{array}{l}\text { Middle } \\
\dagger(\text { Gdowwa })\end{array}$ & $\begin{array}{l}\text { - Land area } 0.50-0.75 \text { ha } \\
\text { - Have large traditional house } \\
\text { - } 2-3 \text { dairy cattle } \\
\text { - } 1-2 \text { oxen } \\
\text { - } 1 \text { donkey } \\
\text { - Cash savings } \\
\text { - Store agricultural products for sale } \\
\text { - Do not buy agricultural products from market } \\
\text { - Enough enset plantation for family consumption } \\
\text { - } 5-7 \text { flowering enset plants } \\
\text { - Small number of coffee plants } \\
\text { - Small number of eucalyptus trees }\end{array}$ & 35 \\
\hline $\begin{array}{l}\text { Poor } \\
\dagger(\text { Manko) }\end{array}$ & $\begin{array}{l}\text { - Land area } 0.25 \text { ha } \\
\text { - Small house, not well constructed } \\
\text { - Feed and shelter dairy cow of richer, to obtain milk and manure } \\
\text { - Do not have more than } 2 \text { sheep or goats } \\
\text { - No oxen } \\
\text { - No large enset plants in the field } \\
\text { - Plant enset only for corm production } \\
\text { - Do not have money to pay for medication or tax } \\
\text { - Usually lease land to rich } \\
\text { - Sell labour to the rich }\end{array}$ & 53 \\
\hline
\end{tabular}

$\dagger$ Local names for rich, middle, and poor households

$47 \%$ in Sidama, Hadiya, and Wolaita respectively. In all three regions wealthier farmers had more land and livestock and produced more crops for sale, while poorer farmers had little land, few livestock and consumed agricultural products immediately after harvest. Poor farmers cannot afford to buy improved seeds, fertilizers, or herbicides. They lease their land and sell their labour to rich farmers. 
Table 3. Wealth ranking by community leaders and key informants in Ambicho-Gode, Hadiya region.

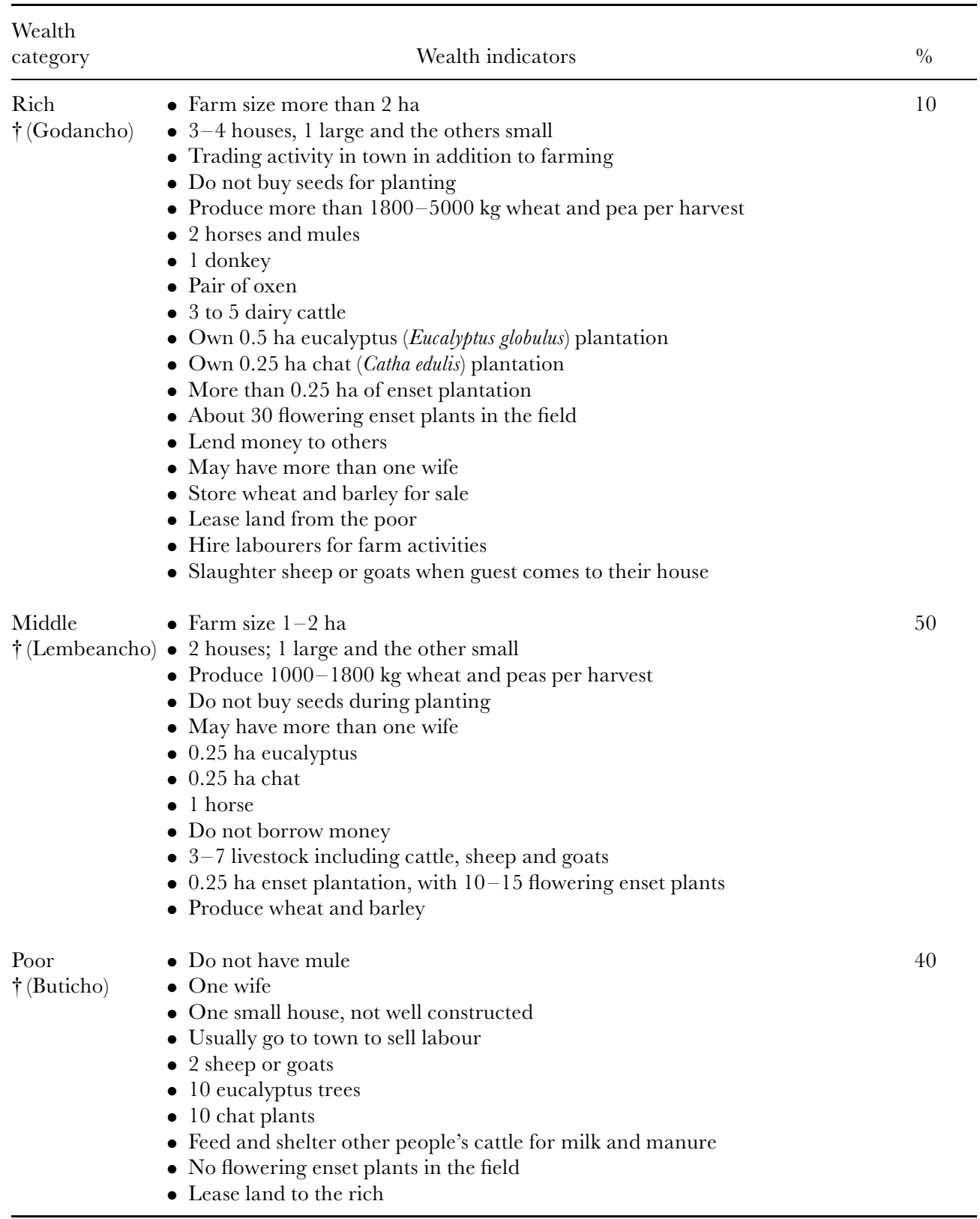

$\dagger$ Local names for rich, middle-income and poor households

\section{Propagation}

Sidama region. Enset is propagated vegetatively from the corm of an immature plant. The plants produce suckers mainly in March but small numbers of suckers are also available in October. To prepare propagation material, farmers take a 
four-year-old enset plant, locally called 'simancho', and cut it 100-150 mm above the junction of the pseudostem and corm. They scrape out the central part of the corm until the growing bud is removed and the corm is then placed in shade for $2-3$ days to allow the wound to heal. The healed corms are planted in fallow land near the house at a spacing of about $0.8 \times 0.8 \mathrm{~m}$. The size of a planting hole depends on the size of the corm. In most cases, soil and then animal manure and household refuse are placed on top of the planted corms. The suckers, locally called 'funta', appear after 2-3 months and remain undisturbed for at least a year.

Wolaita region. As in Sidama, Wolaita farmers propagate enset vegetatively. To do this, they uproot an immature enset plant and cut the pseudostem about $100-150 \mathrm{~mm}$ above its junction with the corm. The corm is then split into two equal parts, the central growing bud is removed and the two halves are exposed to the sun for 2-3 days. The split corms are planted in well-prepared holes near the house before the beginning of the rainy season in December or January and are covered with soil and animal manure. Numerous new shoots, locally called 'osha hatta', emerge from each corm after 2-3 months. These suckers are left in the same place for at least one year.

Hadiya region. As in the Sidama and Wolaita regions, enset is propagated vegetatively using the corm of an immature plant. Farmers uproot a three-yearold enset plant, locally called 'kiniba', and cut the pseudostem 100-150 mm above its junction with the corm. To remove the central growing bud, a hole is bored in the centre of the corm and this is filled with dried mud. The prepared corms are then stored in shade for 2-3 days if there is rain, or planted immediately at a spacing of $1.0 \times 1.0 \mathrm{~m}$ if there is no rain. The suckers that emerge after 2-3 months are called 'dubo', and remain in the same place for at least one year.

\section{Transplanting}

Sidama region. After almost a year the mother corms are uprooted and the suckers ('funta') are removed. The leaves and top part of each sucker are cut. The cutting of the leaves is thought to stimulate growth after transplantation. With the onset of the rainy season, Sidama farmers plant these suckers in their fields, with a narrow spacing of $0.75 \times 0.75 \mathrm{~m}$. Plants that appear thin and unpromising are transplanted for a second time into another field; locally, these suckers are called 'dukullo'. The enset sucker or plant gains a new name for each year during the process of development from sucker into mature plant: 'awulo' or 'kasha' (oneyear-old plant in the final field), 'qora' (two-years-old), 'qatalo' (three-years-old), 'simancho' (four-years-old), 'malancho' (five-years-old), 'itancho' (six-years-old), and 'kalimo' (flowering enset). For sucker production 'simanchoes' are uprooted, whereas for immediate corm consumption 'malanchoes' are utilized.

Wolaita region. After the beginning of the rains in mid-January or February, 
Wolaita farmers uproot the mother corms and separate the suckers ('osha hatta'). The leaves and the top part of the plant are cut. The suckers are then transplanted with a narrow spacing of $0.50-0.70 \mathrm{~m}$ between rows and $0.30-0.35 \mathrm{~m}$ between plants. The enset suckers, locally called 'bashaashwa' at this stage, remain in the same field for 1-2 years depending on soil fertility. In the second or third year, farmers transplant the enset suckers ('bashaashwa') into a final field at a spacing of $1.0 \times 1.0 \mathrm{~m}$. The enset plants are locally known as 'garrdwa' at this stage and remain in the same field until they reach maturity or are uprooted for food. The local term for a large enset plant nearing maturity is 'alla'.

Hadiya region (Figure 2). As in the Sidama and Wolaita ethnic regions, Hadiya farmers transplant with the onset of the rainy season, uprooting the mother corms and separating the suckers ('dubo'). They also cut off the leaves and top part of the plants. In the first year, small suckers are transplanted in groups of $3-5$ into a single hole, while larger ones are transplanted in groups of two. Hole spacing is $0.5 \times 0.5 \mathrm{~m}$. The groups of 3-5 suckers are usually transplanted between rows of groups of two corms. At this stage the suckers are called 'sima'. They remain in the same place for one year. In the second year, suckers that were in groups of two are transplanted separately - these individual suckers are now called 'ogoja'. Suckers that were in groups of 3-5 are transplanted in groups of $2-3$, and called 'lammo'. Spacing is now $0.8 \times 0.8 \mathrm{~m}$, usually with 'lammo' suckers planted in alternate rows with 'ogoja' plants. These larger 'ogoja' plants take the name 'erro' after the third year, but are not transplanted then. The 'lammo' suckers are transplanted at a spacing of $0.8 \times 0.8 \mathrm{~m}$, and take the name 'ogoja'. In the fourth year, the 'erro' plants, which have been in the same place for two years, are transplanted to a permanent site at a spacing of $2.0 \times 2.0 \mathrm{~m}$. The smaller 'ogoja' plants also remain undisturbed in the fourth year, but individuals are transplanted in the fifth year to another field at a spacing of $2.0 \times 2.0 \mathrm{~m}$. The 'erro' plants that are transplanted to a permanent site at a spacing of $2.0 \times 2.0 \mathrm{~m}$ are known locally as 'ballesa'.

\section{Weeding, leaf pruning and fertilization}

There are no clear differences between the weeding, hoeing, or fertilization methods of the three regions. Farmers weed by hand or slash with a sickle, and use a digging spade or fork to loosen the soil. Weeding and slashing is done more frequently in earlier growth stages or during the rainy season (May-October). Depending on the amount of rain and the age of the plant, weeding can occur 2-3 times a season. Deep hoeing is practised in the dry season to kill weeds such as Cynodon dactylon or Cyperus rotundus.

Leaf pruning practices do vary between the regions. Wolaita farmers prune enset leaves severely for animal feed or sale, whereas Sidama farmers usually use thinned enset plants for animal feed, except during the dry season. In Hadiya, again except in the dry season, severe leaf pruning is not practised.

Within the traditional production systems, animal manure plays an important 


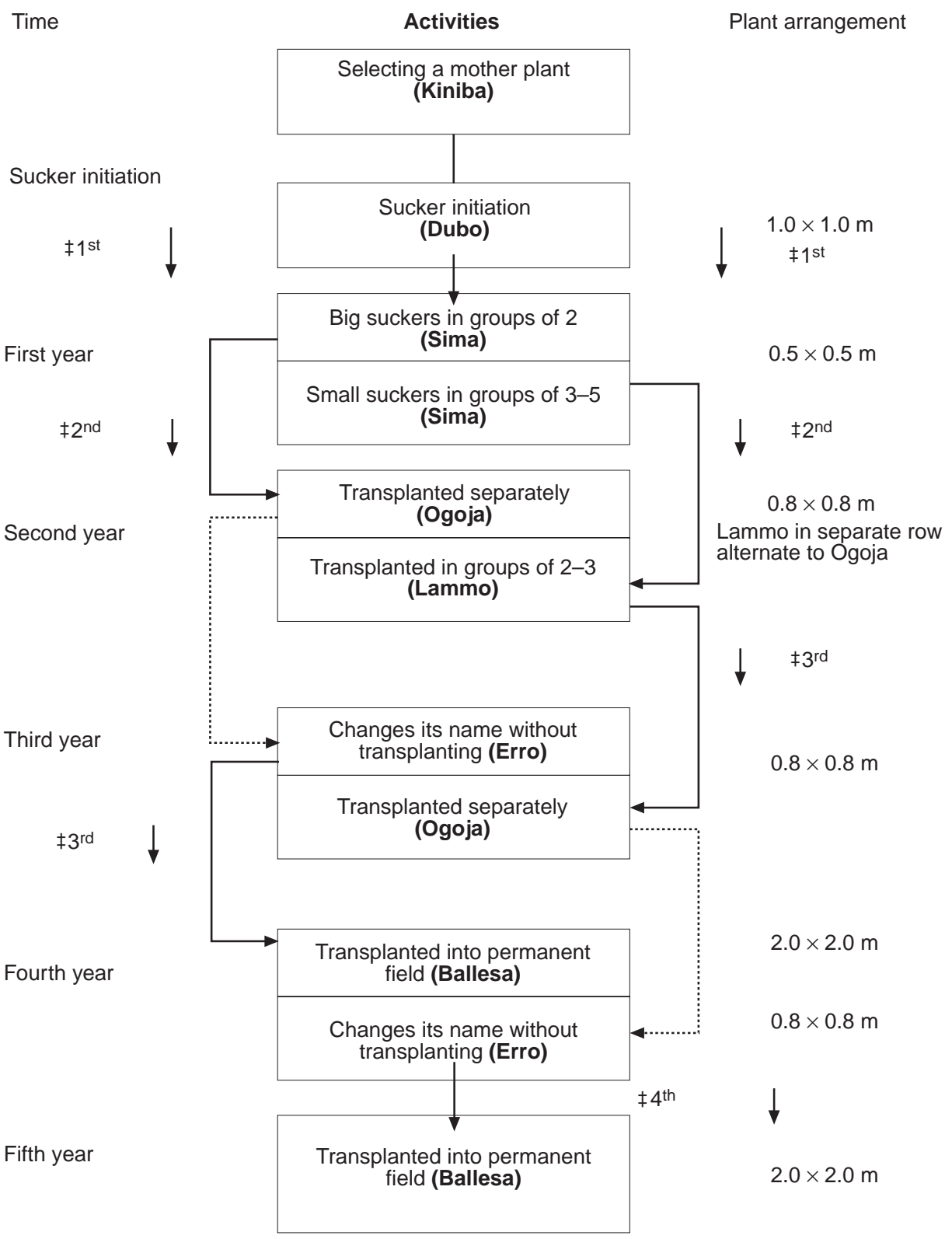

Figure 2. Enset planting flow-chart in the Hadiya region. Words in parentheses indicate the local name of suckers or plants in a particular phase. The enset plant requires three to four years to mature after transplanting to a permanent site.

$\$$ Indicates numbers of repeat transplantings. 
role in maintaining soil fertility. The enset crops are grown closest to the house so that the enset field can easily be fertilized with livestock manure and household refuse. Farmers claim that they cannot produce enset without animal manure. Poor farmers may borrow an animal from a rich farmer to obtain manure and milk because they cannot afford to purchase one.

The rate, timing and method of manure application vary among households and depend on the growth stage of the plantation and the availability of manure. Although it proved difficult to determine the actual application rates, according to the informants and to the authors' own observations, this rate decreases as the age of the plantation increases. When manure is available, farmers do a heavy application in the wettest months (June to August). Otherwise, they apply manure daily until all individual enset plants have received manure. Every day fresh manure is collected and piled between the enset plants. Once the manure starts to break down, it is spread in a circle. Also, urine is channelled to the plantation from the household.

\section{Planting pattern}

Farmers in Sidama start with a relatively dense plantation with no definite pattern of planting and this is thinned to eliminate the less promising plants. As a result, some plants never develop fully and have a stunted appearance. The advantage of this system is that the dense leaf canopy conserves soil moisture, suppresses weed growth and reduces organic matter decomposition by reducing soil temperature. In addition, this type of planting pattern makes full use of the land. The main disadvantages are that other crops cannot be intercropped during the early stages of enset growth, and the thinned enset plants that are used for food are only half-grown. In Hadiya and Wolaita, the authors observed a clear pattern where plants are transplanted every one or two years.

In all the three regions, farms in the rich or middle-wealth ranks were fenced and free from weeds. Enset plants at different stages of development were also planted in separate groups, forming a particular pattern. This was not the case on the farms of poor householders. The severity of bacterial wilt seemed to be high in these poor farms, indicating that sanitary measures and fencing with trees or bamboo might help to reduce infection.

\section{Enset biodiversity}

The number of enset landraces identified in Sidama, Wolaita and Hadiya regions were 52, 55 and 59 respectively (Tables 4, 5 and 6). Each vernacular name represents a morphologically distinct enset landrace. The average number of enset landraces per farm was significantly higher in Sidama than in Walaita and Hadiya (Table 7). The average number of distinct enset types per farm varied between nine and 14 across the three regions. Farmers have multiple uses for these landraces including food, fibre, fodder, fuel, medicine and construction. Across all the regions, however, household consumption was the most important use. 
Table 4. Frequency of enset landraces (\%) in Sidama region, Hagereselam, for each wealth category.

\begin{tabular}{|c|c|c|c|c|c|c|}
\hline No & $\begin{array}{l}\text { Vernacular } \\
\text { name }\end{array}$ & $\begin{array}{c}\text { Rich } \\
(12 \%)\end{array}$ & $\begin{array}{l}\text { Middle } \\
(62 \%)\end{array}$ & $\begin{array}{l}\text { Poor } \\
(26 \%)\end{array}$ & Mean & $\begin{array}{l}\text { Weighted } \\
\text { average }\end{array}$ \\
\hline 1 & Midasho & 97 & 100 & 97 & 98 & 98.8 \\
\hline 2 & Genticha & 100 & 94 & 91 & 95 & 93.9 \\
\hline 3 & Gulumo & 100 & 100 & 80 & 93 & 94.8 \\
\hline 4 & Bira & 89 & 89 & 77 & 85 & 85.9 \\
\hline 5 & Chacho & 86 & 74 & 71 & 77 & 74.7 \\
\hline 6 & Addo & 77 & 74 & 77 & 76 & 75.1 \\
\hline 7 & Kiticho & 80 & 86 & 57 & 74 & 77.7 \\
\hline 8 & Derassa addo & 74 & 57 & 69 & 67 & 62.2 \\
\hline 9 & Gossalo & 54 & 68 & 63 & 62 & 65.0 \\
\hline 10 & Astara & 68 & 54 & 34 & 52 & 50.5 \\
\hline 11 & Kule & 54 & 54 & 49 & 52 & 52.7 \\
\hline 12 & Alaticho & 47 & 49 & 47 & 48 & 48.2 \\
\hline 13 & Gedmo & 37 & 63 & 29 & 43 & 51.0 \\
\hline 14 & Keshe/Kire & 49 & 37 & 29 & 38 & 36.4 \\
\hline 15 & Uwesho & 37 & 37 & 26 & 33 & 34.1 \\
\hline 16 & Mundurare & 37 & 31 & 23 & 30 & 29.6 \\
\hline 17 & Haho & 31 & 29 & 14 & 25 & 25.3 \\
\hline 18 & Micho & 17 & 20 & 29 & 22 & 21.9 \\
\hline 19 & Bufare & 23 & 17 & 23 & 21 & 19.3 \\
\hline 20 & Wanikore & 29 & 20 & 14 & 21 & 19.5 \\
\hline 21 & Damala & 17 & 17 & 14 & 16 & 16.2 \\
\hline 22 & Goticho & 26 & 9 & 9 & 15 & 11.0 \\
\hline 23 & Borbodancho & 23 & 17 & 3 & 14 & 14.1 \\
\hline 24 & Dobramo & 11 & 17 & 9 & 12 & 14.2 \\
\hline 25 & Lemicho & 17 & 9 & 11 & 12 & 10.5 \\
\hline 26 & Agena & 20 & 6 & 6 & 11 & 7.7 \\
\hline 27 & Kincho & 14 & 9 & 6 & 10 & 8.8 \\
\hline 28 & Gamachela & 17 & 3 & 9 & 10 & 6.2 \\
\hline 29 & Adami & 3 & 14 & 9 & 9 & 11.4 \\
\hline 30 & Made & 3 & 14 & 11 & 9 & 11.9 \\
\hline 31 & Bullo & 11 & 11 & 6 & 9 & 9.7 \\
\hline 32 & Siltite & 14 & 6 & 6 & 9 & 6.9 \\
\hline 33 & Aydara & 9 & 11 & 3 & 8 & 8.7 \\
\hline 34 & Molagna & 11 & 14 & 0 & 8 & 10.0 \\
\hline 35 & Shewite & 6 & 9 & 9 & 8 & 8.6 \\
\hline 36 & Birbo & 6 & 6 & 9 & 7 & 6.8 \\
\hline 37 & Garircho & 6 & 9 & 3 & 6 & 7.1 \\
\hline 38 & Chacho & 0 & 6 & 9 & 5 & 6.1 \\
\hline 39 & Hamesesa & 6 & 3 & 3 & 4 & 3.4 \\
\hline 40 & Nefo & 6 & 3 & 3 & 4 & 3.4 \\
\hline 41 & Wubisho & 3 & 0 & 6 & 3 & 1.9 \\
\hline 42 & Dergicha & 6 & 3 & 0 & 3 & 2.6 \\
\hline 43 & Hekeche & 3 & 3 & 0 & 2 & 2.2 \\
\hline 44 & Siriro & 6 & 0 & 0 & 2 & 0.7 \\
\hline 45 & Gena & 6 & 0 & 0 & 2 & 0.7 \\
\hline 46 & Garbo & 3 & 3 & 0 & 2 & 2.2 \\
\hline 47 & Meleket & 0 & 6 & 0 & 2 & 3.7 \\
\hline 48 & Kanda & 3 & 0 & 0 & 1 & 0.4 \\
\hline 49 & Ambula & 3 & 0 & 0 & 1 & 0.4 \\
\hline 50 & Arisho & 3 & 0 & 0 & 1 & 0.4 \\
\hline 51 & Awulecho & 0 & 0 & 3 & 1 & 0.8 \\
\hline 52 & Saranna & 0 & 0 & 3 & 1 & 0.8 \\
\hline
\end{tabular}


A. TSEGAYE AND P. G. STRUIK

Table 5. Frequency of enset landraces (\%) in Wolaita region, Boloso Sore Woreda, for each wealth category.

\begin{tabular}{|c|c|c|c|c|c|c|}
\hline No & $\begin{array}{l}\text { Vernacular } \\
\text { name }\end{array}$ & $\begin{array}{l}\text { Rich } \\
(12 \%)\end{array}$ & $\begin{array}{c}\text { Middle } \\
(35 \%)\end{array}$ & $\begin{array}{l}\text { Poor } \\
(53 \%)\end{array}$ & Mean & $\begin{array}{l}\text { Weighted } \\
\text { average }\end{array}$ \\
\hline 1 & Ankogena & 80 & 94 & 60 & 78 & 74.3 \\
\hline 2 & Kuchia & 86 & 74 & 74 & 78 & 75.4 \\
\hline 3 & Alagena & 69 & 57 & 49 & 78 & 54.2 \\
\hline 4 & Kabaria & 74 & 57 & 34 & 58 & 47.0 \\
\hline 5 & Nakaka & 54 & 49 & 37 & 48 & 43.2 \\
\hline 6 & Shalakumia & 54 & 51 & 31 & 45 & 40.8 \\
\hline 7 & Suitia & 40 & 43 & 49 & 44 & 45.8 \\
\hline 8 & Wanadia & 51 & 37 & 31 & 40 & 36.0 \\
\hline 9 & Peluwa & 57 & 40 & 23 & 40 & 33.0 \\
\hline 10 & Aginia & 57 & 37 & 23 & 39 & 32.0 \\
\hline 11 & Silkantia & 34 & 37 & 40 & 37 & 38.2 \\
\hline 12 & Chichia & 46 & 40 & 26 & 37 & 33.3 \\
\hline 13 & Gefetanuwa & 37 & 20 & 29 & 25 & 26.8 \\
\hline 14 & Tuzuma & 34 & 20 & 17 & 24 & 20.1 \\
\hline 15 & Sirarea & 14 & 37 & 14 & 22 & 20.1 \\
\hline 16 & Dalulia & 23 & 26 & 17 & 22 & 21.0 \\
\hline 17 & Zinkia & 20 & 29 & 14 & 21 & 20.0 \\
\hline 18 & Bundwa & 17 & 20 & 17 & 18 & 18.1 \\
\hline 19 & Arkia & 26 & 9 & 6 & 14 & 9.5 \\
\hline 20 & Matia & 17 & 11 & 11 & 13 & 11.7 \\
\hline 21 & Masmasa & 17 & 6 & 6 & 10 & 7.3 \\
\hline 22 & Adnona & 11 & 9 & 9 & 10 & 9.2 \\
\hline 23 & Halla & 9 & 14 & 3 & 9 & 7.6 \\
\hline 24 & Mazia & 17 & 6 & 3 & 9 & 5.7 \\
\hline 25 & Lembuwa & 9 & 17 & 0 & 9 & 7.0 \\
\hline 26 & Godaria & 9 & 11 & 0 & 7 & 4.9 \\
\hline 27 & Tenna & 9 & 11 & 0 & 7 & 4.9 \\
\hline 28 & Benuwa & 11 & 0 & 6 & 7 & 4.5 \\
\hline 29 & Pena & 11 & 0 & 3 & 5 & 2.9 \\
\hline 30 & Doko & 9 & 6 & 0 & 5 & 3.2 \\
\hline 31 & Lochingia & 3 & 6 & 6 & 5 & 5.6 \\
\hline 32 & Katania & 6 & 3 & 3 & 5 & 3.4 \\
\hline 33 & Bukunia & 6 & 3 & 3 & 5 & 3.4 \\
\hline 34 & Banga & 3 & 6 & 0 & 3 & 2.5 \\
\hline 35 & Kuania & 3 & 6 & 0 & 3 & 2.5 \\
\hline 36 & Hawsakuwa & 6 & 3 & 0 & 3 & 1.8 \\
\hline 37 & Budaro & 0 & 6 & 0 & 2 & 2.1 \\
\hline 38 & Separa & 6 & 0 & 0 & 2 & 0.7 \\
\hline 39 & Kekeruwa & 0 & 0 & 3 & 1 & 1.6 \\
\hline 40 & Argama & 3 & 0 & 0 & 1 & 0.4 \\
\hline 41 & Genesa & 0 & 0 & 3 & 1 & 1.6 \\
\hline 42 & Afamma & 0 & 3 & 0 & 1 & 1.1 \\
\hline 43 & Badadia & 0 & 3 & 0 & 1 & 1.1 \\
\hline 44 & Achaka & 0 & 3 & 0 & 1 & 1.1 \\
\hline 45 & Sanka & 0 & 0 & 3 & 1 & 1.6 \\
\hline 46 & Shamaruwa & 0 & 3 & 0 & 1 & 1.1 \\
\hline 47 & Tagacha & 0 & 0 & 0 & 1 & 1.1 \\
\hline 48 & Mahia & 0 & 0 & 3 & 1 & 1.6 \\
\hline 49 & Gonwassa & 3 & 0 & 0 & 1 & 0.4 \\
\hline 50 & Mochia & 3 & 0 & 0 & 1 & 0.4 \\
\hline 51 & Siskela & 3 & 0 & 0 & 1 & 0.4 \\
\hline 52 & Chorore & 3 & 0 & 0 & 1 & 0.4 \\
\hline 53 & Fara & 3 & 0 & 0 & 1 & 0.4 \\
\hline 54 & Gishera & 3 & 0 & 0 & 1 & 0.4 \\
\hline 55 & Guniashia & 3 & 0 & 0 & 1 & 0.4 \\
\hline
\end{tabular}


Table 6. Frequency of enset landraces (\%) in Hadyia region, Ambicho Gode and Anna-lemmo, for each wealth category.

\begin{tabular}{|c|c|c|c|c|c|c|}
\hline No & $\begin{array}{l}\text { Vernacular } \\
\text { name }\end{array}$ & $\begin{array}{r}\text { Rich } \\
(12 \%)\end{array}$ & $\begin{array}{c}\text { Middle } \\
(62 \%)\end{array}$ & $\begin{array}{l}\text { Poor } \\
(26 \%)\end{array}$ & Mean & $\begin{array}{l}\text { Weighted } \\
\text { average }\end{array}$ \\
\hline 1 & Gimbo & 100 & 97 & 96 & 98 & 96.9 \\
\hline 2 & Sapara & 94 & 79 & 81 & 85 & 81.3 \\
\hline 3 & Siskela & 88 & 82 & 78 & 83 & 81.0 \\
\hline 4 & Hayiwona & 82 & 85 & 67 & 78 & 77.5 \\
\hline 5 & Disho & 71 & 64 & 48 & 61 & 58.3 \\
\hline 6 & Gishera & 68 & 55 & 48 & 57 & 55.5 \\
\hline 7 & Merza & 53 & 61 & 37 & 50 & 50.6 \\
\hline 8 & Oniya & 56 & 39 & 33 & 43 & 38.3 \\
\hline 9 & Unjama & 38 & 45 & 37 & 40 & 41.1 \\
\hline 10 & Zobra & 44 & 36 & 37 & 39 & 37.2 \\
\hline 11 & Shate & 50 & 39 & 22 & 37 & 33.3 \\
\hline 12 & Manduluka & 35 & 36 & 37 & 36 & 36.3 \\
\hline 13 & Torora & 41 & 30 & 37 & 36 & 33.9 \\
\hline 14 & Astara & 35 & 33 & 19 & 29 & 27.6 \\
\hline 15 & Beneja & 32 & 18 & 19 & 23 & 19.8 \\
\hline 16 & Agade & 29 & 18 & 19 & 22 & 19.5 \\
\hline 17 & Uskruz & 21 & 24 & 18 & 21 & 21.3 \\
\hline 18 & Kombotra & 29 & 21 & 11 & 20 & 17.8 \\
\hline 19 & Hiniba & 29 & 21 & 4 & 18 & 15.0 \\
\hline 20 & Kaseta & 26 & 12 & 15 & 18 & 14.6 \\
\hline 21 & Kiniwar & 26 & 15 & 11 & 17 & 14.5 \\
\hline 22 & Orada & 18 & 18 & 11 & 16 & 15.2 \\
\hline 23 & Gariya & 24 & 18 & 4 & 15 & 13.0 \\
\hline 24 & Woshamaja & 15 & 12 & 15 & 14 & 13.5 \\
\hline 25 & Bedadeda & 24 & 12 & 7 & 14 & 11.2 \\
\hline 26 & Mesmesicho & 26 & 9 & 0 & 12 & 7.1 \\
\hline 27 & Moche & 12 & 9 & 15 & 12 & 11.7 \\
\hline 28 & Hanzena & 12 & 18 & 4 & 11 & 11.8 \\
\hline 29 & Dirbo & 24 & 9 & 0 & 11 & 6.9 \\
\hline 30 & Tebute & 9 & 9 & 7 & 8 & 8.2 \\
\hline 31 & Gozoda & 12 & 9 & 4 & 8 & 7.3 \\
\hline 32 & Sormanicho & 15 & 3 & 7 & 8 & 5.8 \\
\hline 33 & Korina & 3 & 9 & 11 & 8 & 9.2 \\
\hline 34 & Bekecho & 9 & 9 & 4 & 7 & 7.0 \\
\hline 35 & Shewrad & 12 & 3 & 4 & 6 & 4.3 \\
\hline 36 & Necho & 12 & 6 & 0 & 6 & 4.2 \\
\hline 37 & Dego & 6 & 6 & 4 & 5 & 5.2 \\
\hline 38 & Sokido & 3 & 9 & 4 & 5 & 6.4 \\
\hline 39 & Mariye & 6 & 3 & 4 & 4 & 3.7 \\
\hline 40 & Tessa & 3 & 9 & 0 & 4 & 4.8 \\
\hline 41 & Eshamwesa & 6 & 6 & 0 & 4 & 3.6 \\
\hline 42 & Lendwesa & 3 & 3 & 7 & 4 & 4.6 \\
\hline 43 & Teigo & 6 & 0 & 4 & 3 & 2.2 \\
\hline 44 & Woshemela & 6 & 0 & 4 & 3 & 2.2 \\
\hline 45 & Memo & 6 & 3 & 0 & 3 & 2.1 \\
\hline 46 & Tegaded & 9 & 0 & 0 & 3 & 0.9 \\
\hline 47 & Onsessa & 6 & 0 & 4 & 3 & 2.2 \\
\hline 48 & Bokucho & 0 & 3 & 4 & 2 & 3.1 \\
\hline 49 & Jegireda & 3 & 3 & 0 & 2 & 1.8 \\
\hline 50 & Anchere & 0 & 0 & 4 & 1 & 1.6 \\
\hline 51 & Mekelesa & 3 & 0 & 0 & 1 & 0.3 \\
\hline
\end{tabular}


Table 6. (contd)

\begin{tabular}{llccccc}
\hline No & $\begin{array}{c}\text { Vernacular } \\
\text { name }\end{array}$ & $\begin{array}{c}\text { Rich } \\
(12 \%)\end{array}$ & $\begin{array}{c}\text { Middle } \\
(62 \%)\end{array}$ & $\begin{array}{c}\text { Poor } \\
(26 \%)\end{array}$ & Mean & $\begin{array}{c}\text { Weighted } \\
\text { average }\end{array}$ \\
\hline 52 & Genko & 3 & 0 & 0 & 1 & 0.2 \\
53 & Arke & 3 & 0 & 0 & 1 & 0.3 \\
54 & Gudere & 0 & 3 & 0 & 1 & 1.5 \\
55 & Awuneda & 0 & 3 & 0 & 1 & 1.5 \\
56 & Amcheroda & 0 & 3 & 0 & 1 & 1.5 \\
57 & Sherafera & 3 & 0 & 0 & 1 & 0.3 \\
58 & Wordes & 3 & 0 & 0 & 1 & 0.3 \\
59 & Sumeka & 3 & 0 & 0 & 1 & 0.3 \\
\hline
\end{tabular}

In all regions, more landraces were grown by rich or average households than by their poorer counterparts (Table 7). On average, poorer households had 30 and $20 \%$ fewer landraces on their farms than did households in the highest and middle-wealth ranks respectively.

The numerous landraces differ with respect to morphological characters (leaf, midrib, petiole and pseudostem colour), use value (kocho, corm and fibre), quality of products, maturity period, vigour and reaction to bacterial wilt (Tsegaye et al., 2001).

\section{Crop species}

The number of crop species recorded in Sidama, Wolaita and Hadiya were 10, 25 and 14 respectively. Enset, wheat (Triticum sp.), barley (Hordeum vulgare), Ethiopian kale (Brassica oleracea), potato (Solanum tuberosum), pepper (Capsicum sp.), common bean (Phaseolus vulgaris), and pumpkin (Cucurbita pepo) were the most common in all three study areas, whereas fruits such as avocado (Persea americana), banana (Musa sp.), mango (Mangifera indica), orange (Citrus sinensis) and passion fruit (Passiflora edulis) were only common in Wolaita. There was a significant difference in the average number of crop species between the three regions, with Wolaita farmers growing substantially more types of crops than in Sidama or Hadiya (Table 7). The crops grown in the study areas are used to supplement the low protein and vitamin content of enset products and to generate cash from sales.

There was a significant difference in the average number of crop species between the three wealth categories in Wolaita, with the average rich household growing $47 \%$ and $22 \%$ more crop species than the average poor or middleincome household respectively. In Sidama, poor households grew significantly fewer crop species than either rich or middle-ranked households, while in the Hadiya region there was no significant difference according to wealth rank (Table 7).

\section{Livestock}

The number of livestock per farm differed significantly between the three regions (Table 7), with fewer livestock in Wolaita than in Sidama or Hadiya. 
Table 7. Average number of enset landraces, crop species, livestock, family and farm size of each wealth category in Sidama, Wolaita and Hadiya ethnic regions.

\begin{tabular}{|c|c|c|c|c|c|}
\hline $\begin{array}{l}\text { Region/wealth } \\
\text { category }\end{array}$ & $\begin{array}{c}\text { Number of } \\
\text { enset landraces }\end{array}$ & $\begin{array}{l}\text { Number of } \\
\text { crop species }\end{array}$ & $\begin{array}{l}\text { Number of } \\
\text { livestock }\end{array}$ & $\begin{array}{l}\text { Farm size } \\
\text { (ha) }\end{array}$ & $\begin{array}{c}\text { Family size } \\
\text { (number) }\end{array}$ \\
\hline & & & Mean & & \\
\hline Sidama & $13.9(1.2) \dagger$ & $3.0(0.6)$ & $12.4(1.1)$ & $1.7(0.4)$ & $8.9(0.9)$ \\
\hline Wolaita & $8.8(0.9)$ & $10.9(1.0)$ & $4.5(0.7)$ & $0.7(0.2)$ & $7.4(0.9)$ \\
\hline Hadiya & $11.7(1.1)$ & $6.0(0.8)$ & $6.1(0.8)$ & $1.0(0.3)$ & $8.2(0.9)$ \\
\hline Mean & $11.5(1.1)$ & $6.6(0.8)$ & $7.7(0.9)$ & $1.1(0.3)$ & $8.2(0.9)$ \\
\hline \multirow[t]{2}{*}{ s.e.mean } & $(0.05)$ & $(0.05)$ & $(0.05)$ & $(0.04)$ & $(0.05)$ \\
\hline & & & Sidama & & \\
\hline $\operatorname{Rich}(\mathrm{n}=35)$ & $15.6(1.2)$ & $3.2(0.6)$ & $22.3(1.3)$ & $2.6(0.5)$ & $11.7(1.1)$ \\
\hline Middle $(\mathrm{n}=35)$ & $14.4(1.2)$ & $3.3(0.6)$ & $10.3(1.0)$ & $1.5(0.4)$ & $8.7(0.9)$ \\
\hline Poor $(n=35)$ & $11.6(1.1)$ & $2.5(0.5)$ & $4.6(0.7)$ & $0.7 \quad(0.2)$ & $6.3(0.8)$ \\
\hline Mean & $13.9(1.2)$ & $3.0(0.6)$ & $12.4(1.0)$ & $1.7(0.4)$ & $8.9(0.9)$ \\
\hline \multirow[t]{2}{*}{ s.e.mean } & $(0.07)$ & $(0.05)$ & $(0.11)$ & $(0.06)$ & $(0.09)$ \\
\hline & & & Wolaita & & \\
\hline Rich $(n=35)$ & $10.8(1.0)$ & $13.1(1.1)$ & $7.0(0.9)$ & $1.0(0.3)$ & $9.4(0.9)$ \\
\hline Middle $(\mathrm{n}=35)$ & $9.0(0.9)$ & $10.8(1.1)$ & $4.2(0.7)$ & $0.7 \quad(0.2)$ & $7.2(0.9)$ \\
\hline Poor $(n=35)$ & $6.6(0.9)$ & $8.9(0.9)$ & $2.3(0.5)$ & $0.4(0.1)$ & $5.6(0.8)$ \\
\hline Mean & $8.8(0.9)$ & $10.9(1.0)$ & $4.5(0.7)$ & $0.7(0.2)$ & $7.4(0.9)$ \\
\hline \multirow[t]{2}{*}{ s.e.mean } & $(0.11)$ & $(0.07)$ & $(0.08)$ & $(0.03)$ & $(0.09)$ \\
\hline & & & Hadiya & & \\
\hline Rich $(n=35)$ & $13.3(1.1)$ & $6.3(0.8)$ & $9.7(1.0)$ & $1.3(0.4)$ & $9.2(0.9)$ \\
\hline Middle $(\mathrm{n}=35)$ & $12.4(1.1)$ & $6.1 \quad(0.8)$ & $6.1 \quad(0.8)$ & $1.1(0.3)$ & $8.3(0.9)$ \\
\hline Poor $(n=35)$ & $9.4(1.0)$ & $5.7(0.8)$ & $2.5(0.5)$ & $0.7 \quad(0.2)$ & $7.0(0.9)$ \\
\hline Mean & $11.7(1.1)$ & $6.0(0.8)$ & $6.1(0.8)$ & $1.0(0.3)$ & $8.2(0.9)$ \\
\hline s.e.mean & $(0.09)$ & $(0.05)$ & $(0.09)$ & $(0.04)$ & $(0.09)$ \\
\hline
\end{tabular}

$\dagger \log (\mathrm{x}+1)$ transformed data in parentheses

Livestock provide manure for enset and other important crops, and milk to supplement the diet. They can be an important source of cash.

Within each of the three regions, the number of livestock differed significantly among the three wealth categories (Table 7).

\section{Farm size}

A typical farm includes a rectangular compound or field, fenced by eucalyptus trees in Wolaita and Hadiya, and by bamboo in Sidama. In front of the house about $5-10 \%$ of the land is left as a front yard for grazing and for social activities such as funeral and wedding ceremonies.

The household farm size in Sidama was significantly larger than in Wolaita or Hadiya. Farm size also differed between the three wealth categories in the study areas (Table 7). 
Family size

In Sidama, the average family size was significantly higher than in Wolaita, though Hadiya family size was similar to the other locations (Table 7). Family members in Wolaita and Hadiya are mostly involved in crop production activities, while in Sidama, livestock herding and feeding are also important production activities.

The average family size differed significantly with wealth in Sidama and Wolaita, with wealthy households having more members (Table 7). In Hadiya, the family size of poorer households was lower than for those in the middle or wealthiest categories.

\section{Relations between household characteristics}

Correlation coefficients among household characteristics were estimated in the three regions in order to determine patterns of relationships and to assess the impact of household characteristics on enset biodiversity. Only for the resourcerich households in the Sidama region was the number of enset landraces correlated with all assessed household characteristics (Table 8). For resource-rich Hadiya farmers, the number of enset landraces correlated significantly to livestock number and to farm area. However, for the resource-rich group of Wolaita farmers, the number of enset landraces was not correlated to any of the measured household characteristics, though there was a positive correlation with the number of crop species and a negative correlation with family size in resourcepoor households. The absence of a correlation pattern in Wolaita suggests that farmers might be pursuing other off-farm activities - such as trading and handicraft - for their living because of the scarcity of farmland. As family size increases, resource-poor farmers may concentrate on a few high kocho-yielding enset landraces rather than growing diverse landraces with various properties.

\section{Enset and gender}

There is a clear gender division in enset cultivation practice. Men are involved in propagating, planting and transplanting activities. Women are involved in manuring, hand-weeding, thinning and landrace selection. In addition, the tedious work of harvesting and processing is exclusively left to women. It is taboo for men to assist during processing, or even to enter the enset field at this time. The farmers in all the study areas indicated that women have control over the enset field because it is an important source of daily food. Since women are the ones who take care of husbandry and post-harvest handling, they are able to identify all of the different genotypes. In the absence of the housewife, it was very difficult to identify the different landraces produced by household. The farmers in all enset-growing regions consistently indicated the importance of women by saying that 'if women do not harvest and process enset, there would be no food produced from the plant and it would simply be an ornamental plant, as it is in other parts of the world'. 
Table 8. Coefficient of determination $\left(\mathrm{r}^{2}\right)$ among household characteristics for each wealth category in Sidama Wolaita and Hadiya ethnic regions ( $\left.\mathrm{n}=35\right)$.

\begin{tabular}{|c|c|c|c|c|c|c|c|c|c|c|c|c|}
\hline & $\mathrm{El}$ & Cs & $\mathrm{L}$ & $\mathrm{F}$ & $\mathrm{El}$ & Cs & $\mathrm{L}$ & $\mathrm{F}$ & $\mathrm{El}$ & Cs & $\mathrm{L}$ & $\mathrm{F}$ \\
\hline & \multicolumn{4}{|c|}{ Sidama rich } & \multicolumn{4}{|c|}{ Wolaita rich } & \multicolumn{4}{|c|}{ Hadiva rich } \\
\hline Enset landrace (El) & - & & & & - & & & & - & & & \\
\hline Crop species $(\mathrm{Cs})$ & $0.12 *$ & & & & 0.03 & - & & & 0.04 & - & & \\
\hline Livestock $(\mathrm{L})$ & $0.14 *$ & 0.01 & & & 0.04 & 0.03 & & & $0.09 *$ & 0.00 & & \\
\hline Farm size $(\mathbf{F})$ & $0.26 * *$ & 0.00 & 0.00 & & 0.02 & $0.15^{*}$ & 0.00 & & $0.19 *$ & $0.16^{*}$ & 0.00 & \\
\hline Family size $(\mathrm{Fs})$ & $0.12^{*}$ & 0.04 & $0.18 *$ & 0.05 & -0.05 & 0.00 & 0.02 & 0.07 & -0.00 & 0.02 & 0.00 & 0.03 \\
\hline & \multicolumn{4}{|c|}{ Sidama middle } & \multicolumn{4}{|c|}{ Wolaita middle } & \multicolumn{4}{|c|}{ Hadiya Middle } \\
\hline Enset landrace (El) & - & & & & - & & & & - & & & \\
\hline Crop species $(\mathrm{Cs})$ & 0.06 & - & & & $0.20 * *$ & - & & & 0.08 & & & \\
\hline Livestock $(\mathrm{L})$ & -0.01 & 0.01 & - & & -0.00 & 0.02 & & & -0.00 & $-0.21 * *$ & & \\
\hline Farm size $(\mathrm{F})$ & 0.00 & 0.03 & $0.45^{* *}$ & - & 0.00 & 0.07 & 0.02 & & -0.03 & 0.00 & -0.00 & \\
\hline Family size $(\mathrm{Fs})$ & 0.00 & 0.10 & $0.16^{*}$ & $0.27 * *$ & 0.07 & 0.05 & 0.03 & $0.18 *$ & -0.00 & -0.02 & 0.02 & -0.03 \\
\hline & \multicolumn{4}{|c|}{ Sidama poor } & \multicolumn{4}{|c|}{ Wolaita poor } & \multicolumn{4}{|c|}{ Hadiya poor } \\
\hline Enset landrace (El) & - & & & & - & & & & - & & & \\
\hline Crop species (Cs) & 0.07 & - & & & $0.14^{*}$ & - & & & 0.09 & & & \\
\hline Livestock $(\mathrm{L})$ & 0.00 & $0.15^{*}$ & - & & 0.02 & 0.03 & - & & 0.02 & 0.01 & & \\
\hline Farm size $(\mathrm{F})$ & 0.02 & 0.08 & 0.05 & & -0.01 & 0.03 & 0.02 & & -0.02 & -0.04 & 0.00 & \\
\hline Family size $(\mathrm{Fs})$ & 0.00 & $0.15^{*}$ & $0.52^{* *}$ & $0.21 * *$ & $-0.14^{*}$ & -0.05 & -0.00 & 0.08 & -0.00 & 0.00 & 0.04 & -0.00 \\
\hline
\end{tabular}

* and ** significant at $\mathrm{P}<0.05$ and $\mathrm{P}<0.01$ levels of probability, respectively. 
Table 9. Average proportion (\%) of annual household consumption met by major crops for each wealth category in the three survey areas.

\begin{tabular}{|c|c|c|c|c|c|c|c|c|c|}
\hline Crop & Rich & $\begin{array}{l}\text { Sidama } \\
\text { Middle }\end{array}$ & Poor & Rich & $\begin{array}{l}\text { Wolaita } \\
\text { Middle }\end{array}$ & Poor & Rich & $\begin{array}{l}\text { Hadiya } \\
\text { Middle }\end{array}$ & Poor \\
\hline Enset & 85 & 88 & 89 & 19 & 27 & 30 & 60 & 54 & 68 \\
\hline Beans & 1 & 2 & 1 & 5 & 4 & 8 & 1 & 3 & 1 \\
\hline Maize & 1 & - & 1 & 29 & 16 & 17 & 5 & 5 & 1 \\
\hline Root crops & 2 & 1 & 3 & 40 & 48 & 36 & 7 & 7 & 4 \\
\hline Cabbage & 1 & 2 & - & 6 & 4 & 8 & 15 & 21 & 19 \\
\hline Wheat & 5 & 3 & 4 & - & - & - & 7 & 5 & 7 \\
\hline Barley & 5 & 4 & 2 & - & - & - & 5 & 5 & - \\
\hline Teff & - & - & & 1 & 1 & 1 & - & - & - \\
\hline
\end{tabular}

Note: Root and tuber crops include sweet potato, yam, taro and Irish potato.

\section{Production consumption and marketing}

The Central Statistical Authority (1997) estimated the area cultivated with enset to be about 37000,18000 and 13000 ha in Sidama, Hadiya and North Omo (where the Wolaita region is located) respectively. According to the same survey, these zones annually produce about one million, 190000 and $200000 \mathrm{t}$ of kocho respectively.

Table 9 presents the relative contribution of major farm products to total household consumption over an entire year. In the Sidama and Hadiya regions, enset accounted for the largest share of crop produce consumed as food. In the Sidama region, enset's contribution to food needs in January and February is relatively low (about 50\%) compared with other months, as crops such as barley and wheat are harvested at this time. In Hadiya, the share of enset in the household food consumption was more-or-less constant throughout the year. In Wolaita, root and tuber crops such as sweet potato, yam, taro and Irish potato were the most consumed products, followed by enset and maize.

In all three regions the households produce enset predominantly for home consumption, and only a very small proportion of enset products is sold in the local markets.

\section{DISGUSSION}

\section{Cultivation methods}

Cultivation methods such as propagation and transplanting varied mainly between the three ethnic groups rather than between wealth categories within a given group, indicating that cultural background influenced cultivation methods. The Wolaita people claimed that splitting the corm into two or four equal parts would produce too many suckers. Moreover, Wolaita and Hadiya farmers claimed that repetitive transplanting results in more vigorous growth of both pseudostem and corm, which are the main harvestable parts of the plant. 


\section{Wealth classification}

The classification by key informants of farms into wealth classes was not always consistent with the quantitative information provided by the individual farmers. This became obvious when Tables 1-3 were compared with Table 7. Traditionally, farmers are very suspicious and are reluctant to give accurate information about their livestock number, family or farm size. Most farmers believe that counting their family and livestock may result in undesirable events such as illness or death. Providing information about their farm size is also associated with redistribution of land and increases in land tax. The authors tried, however, to minimize the inconsistency by hiring farmers' children from the study areas for enumeration and data collection.

The wealth indicators used to categorize households according to relative wealth or well-being were similar for all three regions. Resource-rich households in the three ethnic regions have common properties that distinguish them from their less well-off neighbours. This shows that differences in wealth categories between households in each location relate primarily to resources rather than to cultural background, ethnicity or agro-ecology. Most of the wealth indicators for the Hadiya study area were similar to those mentioned by Spring et al. (1996).

\section{Enset landraces}

A combination of factors, including household resources, cultural background, population pressure and agro-ecology influence the number of enset landraces on a given farm. An enset garden is thought to require heavy applications of organic matter to be able maintain it during drought periods for food security (Elias et al., 1998). Since the better-off farmers have more resources, notably land, labour and livestock (as a source of manure), they can plant more landraces for specific characteristics even if they are low yielding (Table 7). Poor farmers, however, do not plant a large number of enset landraces as some types do not perform as well as others or need at least 3-4 years to mature. In enset growing regions, planting many different landraces in the backyard is a sign of high status within the community.

Farmers have multiple uses for the enset plant and thus select enset landraces to fit their different needs and constraints. The selection criteria for household use include the quality and quantity of food products, maturation period, disease and drought tolerance, forage and fibre quality, medicinal value, ease of scraping, rapidity of fermentation, quality of corm, and productivity on marginal soils. Since one landrace can never fulfil all criteria, farmers tend to maintain a diverse range of enset types on their farm (Table 7). Farmers' interest in maintaining multiple varieties with contrasting traits to fit different needs and constraints, rather than concentrating on a single variety with a particular trait, has also been reported for maize in southern Mexico (Bellón, 1996; Brush, 1995).

The significant correlation between on-farm diversity of enset landraces and all the household characteristics of resource-rich Sidama households, and with 
livestock numbers and farmland size of resource-rich Hadiya households (Table 8), may suggest that middle- or poor resource farmers concentrate on other annual crops rather than the perennial enset plant. Most resource-limited farmers are short of food at some time in the season and cannot afford to wait until the enset plant matures. Resource-rich Wolaita households are comparable to middle level Sidama or Hadiya households. Thus, it is likely that the Wolaita farmers, irrespective of wealth category, select few enset landraces and also participate in trading, handicrafts and other off-farm income-generating activities.

On average, the Sidama people grow more enset landraces on their farms than do the Wolaita or Hadiya people (Table 7). The Cushitic-speaking Sidama peoples have long been adapted to the cultivation, processing and eating habit of enset (Stanley, 1966). They grow enset in dense plantations as a staple food and are highly dependent upon cattle to produce manure for fertilising the enset fields. They also depend on cattle as a cash source to meet household needs and obligations. Though the Hadiya belong to the same ethno-linguistic family, their culture and language are quite different from the Sidama. The Wolaita people are Omotic, and are characterized by their own distinctive language and culture. Enset is a co-staple with cereals and other tuber crops for both the Wolaita and Hadiya peoples (Westphal, 1975; Brandt et al., 1997). These ethnic groups also differ somewhat in their end-uses of enset. The Wolaita people commonly select enset landraces for the corm, whereas the Sidama and Hadiya peoples grow enset for the kocho yield (starch from the mixture of scraped pseudostem and pulverized corm). Jain (2000) reported on the influence of cultural background on plant species diversity and the uses of plant species for different purposes.

\section{Farm, family size and enset landrace}

The national average farm and family sizes in Ethiopia were reported to be 1.09 ha and 5.17 persons respectively (Zekaria and Abebe, 1996). The average Sidama farm size exceeds the national average by $73 \%$ while average Wolaita and Hadiya farms are respectively 27 and $26 \%$ smaller. As a result, the Sidama farmers keep a large number of livestock and grow more enset. Increasing population pressure in the Wolaita and Hadiya regions has lead to more extensive cultivation to feed the growing population. This, in turn, leads to reduced numbers of livestock and, hence, reduced cash flow from the sale of animal products and less manure to maintain soil fertility for enset cultivation. These conditions have forced farmers to grow fewer enset landraces. This study confirms the statement by Clincotta et al. (2000) that increased population pressure in biodiversity-rich areas increases the risk of plant species extinction.

\section{Crop species}

Wolaita is characterized by low soil fertility and erratic rainfall, and drought periods are common. When droughts destroy their other crops, the Wolaita people depend entirely on enset and harvest whatever they have in the field. This practice, together with the occurrence of bacterial wilt disease, has caused serious 
genetic erosion of enset. The Wolaita farmers plant a higher diversity of annual crops than do the Sidama or Hadiya people, probably as a risk avoidance strategy (Table 7). In this ethnic region, annual, short-cycle root and tuber crops are the most important food source throughout the year (Table 9). The tendency of small farmers to cultivate diverse crop species with different maturation periods and products as a means of coping with heterogeneous and uncertain ecological conditions, has been reported also by Clawson (1985), Scoones (1996) and Netting and Stone (1996). The average number of crop species of the resource-rich farmers in Wolaita (13.1) is similar to the findings (14.4) of Afaw and Woldu (1997) in the same area.

\section{Enset and gender}

Women play a major role in enset landrace selection. Since the processing of enset is laborious and tedious, neighbouring women conduct this activity in workgroups for each household in turn. During such group work the hostess cooks enset corms for the group to consume at the end of the day. In addition, every day women are very busy preparing different kinds of meals from the different products of enset. All these activities allow women to easily identify the clones and to know the specific characteristics and uses of each landrace.

\section{GONGLUSIONS AND REGOMMENDATIONS}

There is variation in the cultivation methods employed by the different ethnic groups, more so than among households within a single group. The cultural and socio-economic determinants responsible for this variation, as well as the advantages and disadvantages of the different cultivation methods, need to be investigated.

Women control the enset fields and are also responsible for harvesting and processing. They have a well-developed knowledge of the enset crop and its biodiversity. Therefore, a gender-sensitive analysis is needed to fully understand the dynamics of enset biodiversity.

The enset production system involves intercropping with diverse crop species as well as landrace mixtures. To improve the production system and increase productivity per unit area, compatible crops for intercropping and the best mixtures of enset landraces need to be investigated.

Under farmers' conditions, the phenotypic variation expressed in enset landraces is enormous. Farmers have managed this diversity for centuries with limited influence from outside. Future research should analyse how cultural and socioeconomic factors influence the way farmers create, manage, utilize and conserve this diversity. Moreover, this genetic variation needs to be assessed using morphological, agronomic and molecular traits in order to develop a strategy to conserve and utilize the existing genetic diversity.

The diversity of enset landraces on-farm is influenced largely by a combination of household resources, cultural background and agro-ecology. 
Livestock production is an important component in enset-based farming systems. Thus, future research and development studies on enset need to include a strong component that alleviates constraints to livestock productivity.

The enset growing areas are densely populated and have rarely experienced famine. Compared with other crops in the area, enset's high yields under low input conditions, tolerance of climatic and environmental fluctuation, storability for long periods of time, multipurpose use, and the cultural value attached to it make enset attractive to farmers in these regions.

Acknowledgements. The authors thank the Norwegian Agency for Development and Co-operation (NORAD) for granting a fund to execute the research. We are grateful to Dr. E. Westphal and Shawn McGuire for useful comments and editorial suggestions. Also, we thank Mr. Amsalu Gobena and Mr. Asmamaw Zemene for assisting in data collection.

\section{REFERENGES}

Asfaw, Z. and Woldu, Z. (1997). Crop associations of home-gardens in Wolaita and Gurage in southern Ethiopia. SINET: Ethiopian Fournal of Science 20 (1):73-90.

Bellón, M. R. (1991). The ethnoecology of maize variety management: A case study from Mexico. Human Ecology 19(3):389-418.

Bellón, M. R. (1996). The dynamics of crop intraspecific diversity: A conceptual framework at the farmer level. Economic Botany 50(1):26-39.

Brandt, S. A., Spring, A., Hiebsch, C., Yntiso, G., Tabogie, E., Diro, M., Woldemichael, G., Tesfaye, S., McCabe, J. T. and Shigeta, M. (1997). The tree against hunger: Enset-Based Agricultural Systems in Ethiopia. American Association for the Advancement of Science with Awassa Agricultural Research Centre, Kyoto University Centre for African Area Studies and University of Florida. Directorate for International Programs 1200 New York Avenue, NW, Washington, DC 20005.

Brush, S. B. (1995). In situ conservation of landraces in centres of crop diversity. Crop Science 35:346-354.

Central Statistical Authority. (1997). Enset sample survey results. Addis Ababa: Ethiopia.

Clawson, D. L. (1985). Harvest security and intraspecific diversity in traditional tropical agriculture. Economic Botany 39 (1):56-67.

Clincotta, R. P, Wisnewskl, J. and Engelman, R. (2000). Human population in the biodiversity hotspots. Nature 404:990-991.

De Walt, R. B. (1994). Using indigenous knowledge to improve agriculture and natural resource management. Human Organisation 53(2):123-130.

Elias, E., Morse, S. and Belshaw, D. G. R. (1998). Nitrogen and phosphorous balances of Kindo Koisha farms in southern Ethiopia. Agriculture, Ecosystems and Environment 71:93-113.

Jain, S. K. (2000). Human aspect of plant diversity. Economic Botany 54 (4):459-470.

Netting, R. McC. and Stone, M. P. (1996). Agro-diversity on a farming frontier: Kofyar smallholders on the Benue plans of central Nigeria. Africa 66 (1):54-69.

Scoones, I. (1996). Crop production in a variable environment: A case study from southern Zimbabwe. Experimental Agriculture 32:291-303.

Spring, A., Haile, B., Tesfaye, S., Abebe, Y., Amaldegn, A., Woldemichael, G., Tabogie, E., Surur, O., Tsegaye, A., Shimeles, S., Habte, T., Menjeye, T. and Tadesse, T. (1996). Enset farming systems in southern region, Ethiopia. Report on a Rapid Rural Appraisal in Gurage, Hadiya, and Sidama zones. Deutsche Gesellschaft für Technische Zusammenarbeit (GTZ), Addis Ababa, Ethiopia, mimeo.

Stanley, S. (1966). Enset in the Ethiopian economy. Ethiopian Geographical fournal 4(1):30-37.

Tsegaye, A. and Struik, P. C. (2000). Research supporting the genetic diversity of enset in southern Ethiopia. In Encouraging diversity. The conservation and development of plant genetic resources, 245-249 (Eds C. Almekinders and W. Boef). London: Intermediate Technology Publications.

Tsegaye, A., Negash, A., Treuren, R. V. and Struik, P. C. (2001). Comparison of enset characterisation 
based on farmers' knowledge and on AFLPs for effective conservation and utilisation of genetic resources in Ethiopia (submitted to Crop Science).

Vavilov, N. I. and Rodin, L. E. (1997). Five Continents. Rome: International Plant Genetic Resource Institute.

Westphal, E. (1975). Agricultural Systems in Ethiopia. Wageningen: Centre for Agricultural Publication and Documentation.

Zekaria, S. and Abebe, W. (1996). Human resources and intensive agriculture in Ethiopia: Problems and prospects. In Sustainable Intensification of Agriculture in Ethiopia, 141-160 (Eds M. Demeke, W. Amha, T. Zegeye, S. Bellete and S. Ehui). Proceedings of the second conference of the Agricultural Economics Society of Ethiopia. 